\title{
RESISTANCE WELDING OF COATED STEEL PLATES IN THE ASPECT OF ENVIRONMENTAL CONDITIONS
}

\author{
J. MATUSIAK and J. WYCIŚLIK \\ Institute of Welding \\ 16-18 Bl. Czeslawa Str., 44-100, Gliwice, Poland. E-mail: joanna.wycislik@is.gliwice.pl
}

\begin{abstract}
In the industry, resistance welding has always been regarded as the process without significant adverse effect on the work environment. The research literature of the last years dealing with investigations into fume and chemical factors of resistance welding was the only reason that has directed the attention of specialists on working safety to the amount and type of pollutants emitted during this process. The article presents research, conducted at Instytut Spawalnictwa in Gliwice, into the emission of pollutants generated during spot resistance welding of steel plates with various protective coatings. The article demonstrates the research station and methodology of determination of total fume, carbon monoxide, nitrogen oxides and organic matters. The examination of fume and gas emission was conducted during resistance welding of electrolytic and hot-dip coated plates, covered with zinc, zinc-iron alloy, aluminium with the admixture of silicon as well as zinc-epoxy double layer coatings. The comparative analysis of the research results was aimed at the determining the impact of coating type and welding current on emission of fumes and gases during resistance welding of plates with different thickness. 17 Ref., 3 Tables, 9 Figures.
\end{abstract}

Keywords : spot resistance welding, coated steel sheets, pollutants emission

In the literature on industrial medicine and research into factor having the adverse impact on the safety work conditions, welding of metal coated plates is associated with a disease called metal fume fever [1-7]. This disease is caused by zinc, aluminium and magnesium compounds. Its symptoms resemble the symptoms of influenza and appear usually approximately four hours after the exposition. In the assessment of occupational hazards the metal fume fever is recognised as the risk appearing very quickly after the exposure to the agents causing the disease. Moreover, the fever is accompanied by the characteristic symptom called «Monday morning fever», consisting in the fact that the patient's condition deteriorates after a longer rest. Repeated occupational expositions to the high concentration of zinc oxides $(\mathrm{ZnO})$ lead to lesions in the respiratory system. The metal fume fever is recognised as a direct reason for asthma development initiated by the occupational agents [3]. During welding of aluminium coated plates, fumes containing aluminium oxide $\mathrm{Al}_{2} \mathrm{O}_{3}$ and silicon dioxide (silica) are the main compounds affecting work conditions and influencing workers health [2]. Aluminium belongs to the elements of toxic action on human body and tends to accumulate in the liver, kidneys, pancreas, bones and brain tissue. Current research data indicate that aluminium reduces the activity of central nervous system, blocking the action potential of neurons.

The process of resistance welding was regarded in the industry as the technology not affecting adversely

(C) J. MATUSIAK and J. WYCIŚLIK, 2016 the work environment. The research results into the issues of the factors harmful to the workers' health during resistance welding performance have drawn the attention of the specialists in industrial safety on the amount and type of pollutants generated by this process.

Resistance welding of paint coated plates or plates covered with combination of metal, paint and organic coatings is associated with the generation of chemical compounds belonging to the aromatic hydrocarbons group, e.g. benzene, toluene, ethyl benzene, xylene, phenol and cresol as well as polycyclic aromatic hydrocarbons (PAHs) to the work environment [4]. Those substances after penetrating into the human body cause poisoning and occupational diseases. During resistance welding of steel plates with protective coatings, fume containing zinc, iron, aluminium, manganese and silicon is always generated while carbon monoxide generation belongs the gas emission process $[5,6]$.

Pollutant emission rate research during resistance welding. This article presents the research conducted in the experimental station at Institute of Welding in Poland aimed at the determination of the correlation between the selected resistance welding parameters and amount of pollutants being generated [8-10]. The investigation into fume and gas generation was conducted for hot-dip coated plates with zinc, zinc-iron alloy coatings as well as with coating of aluminium with admixture of silicon. 
Table 1. Materials used in research into fume and gas generation during spot resistance welding [8-10]

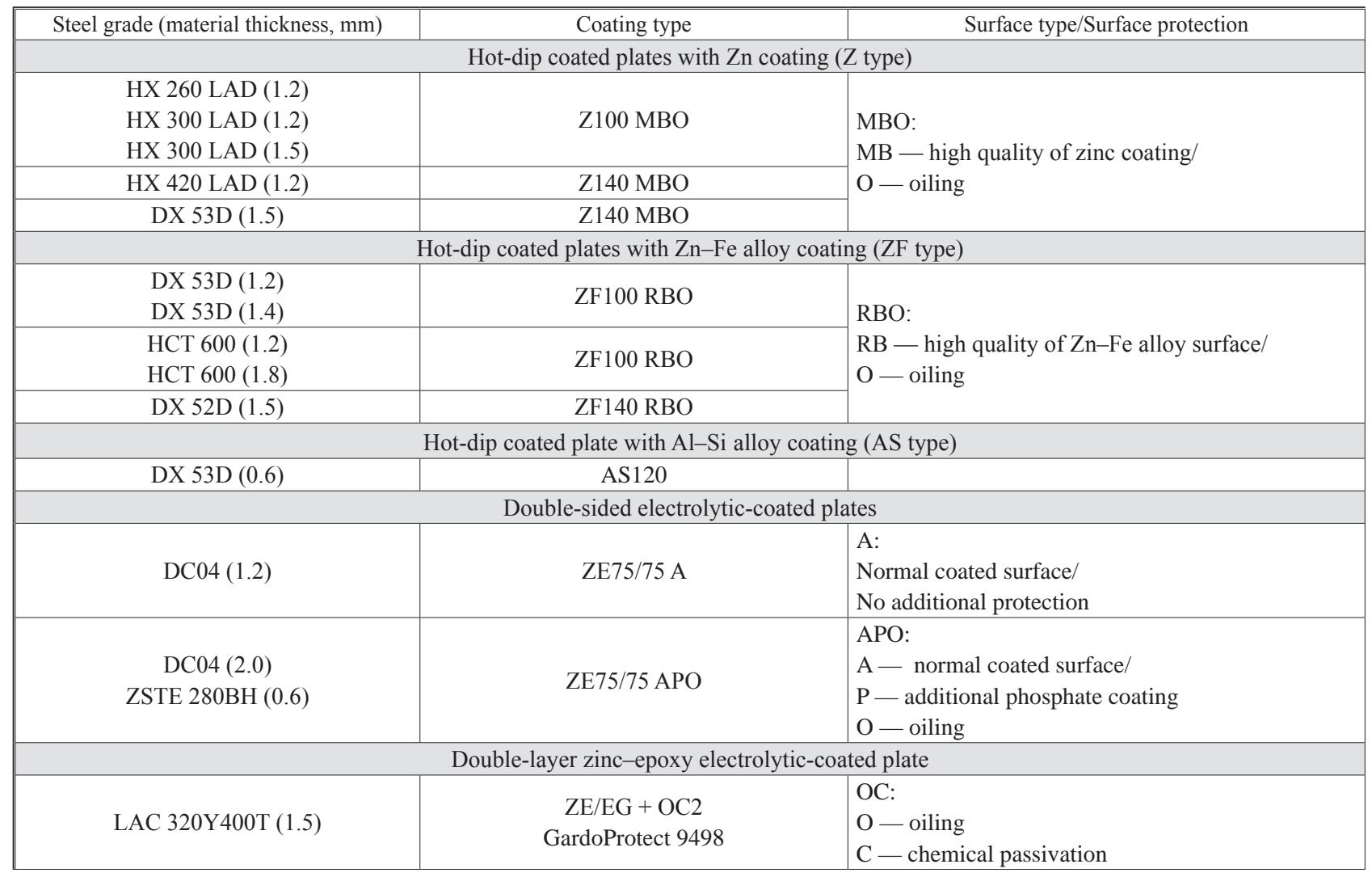

The plates used in research had coating thicknesses from 5 to $20 \mu \mathrm{m}$ with additional surface protection by oiling. The electrolytic-coated plates had $7.5 \mu \mathrm{m}$ thick zinc coating on their both sides and were additionally protected by oiling and phosphating. The investigation of pollutants during spot resistance welding was performed also for electrolytic zinc-coated plates with coating thickness of $5 \mu \mathrm{m}$ with additional coating of $5 \mu \mathrm{m}$ thick epoxy layer. The double-layer coating was protected by oiling and chemical passivation. Materials used during the research into the generation of fume and gas during spot resistance welding are given in Table 1, while Table 2 presents the parameters of resistance welding process.

Research station for the examination of fume and gas generation during resistance welding is composed of the following main components (Figures 1 and 2): fume chamber, exhaust system and spot welding machine of ZPa-130i type with the inverter controller HWS 2102IQ, equipped with computer control system for monitoring current and voltage using the program LOGWELD.

The experimental station and research methodology were developed in accordance with the require-

Table 2. Technological conditions for spot resistance welding used in pollutants emission investigations [8-10]

\begin{tabular}{|c|c|c|c|c|c|}
\hline Material grade & $\begin{array}{c}\text { Plate thickness, } \\
\text { mm }\end{array}$ & $\begin{array}{c}\text { Welding current, } \\
\text { kA }\end{array}$ & $\begin{array}{c}\text { Welding time, } \\
\text { ms }\end{array}$ & $\begin{array}{l}\text { Welding force, } \\
\text { daN }\end{array}$ & $\begin{array}{c}\text { Welding productivity, } \\
\text { weld/min }\end{array}$ \\
\hline HX 260 LAD/Z100 MBO & 1.2 & $9-12$ & 300 & 250 & $22-28$ \\
\hline HX $300 \mathrm{LAD} / \mathrm{Z} 100 \mathrm{MBO}$ & 1.2 & $9-11$ & 300 & 250 & $22-24$ \\
\hline HX $300 \mathrm{LAD} / \mathrm{Z} 100 \mathrm{MBO}$ & 1.5 & $9-11$ & 250 & 300 & $22-24$ \\
\hline $\mathrm{HX} 420 \mathrm{LAD} / \mathrm{Z} 140 \mathrm{MBO}$ & 1.2 & $9-11$ & 300 & 250 & 22 \\
\hline $\mathrm{DX} 53 \mathrm{D} / \mathrm{Z} 140 \mathrm{MBO}$ & 1.5 & $9-12$ & 250 & 300 & 22 \\
\hline DX 53D/ZF100 RBO & 1.2 & $9-12$ & 300 & 250 & $22-24$ \\
\hline DX 53D/ZF100 RBO & 1.4 & $9-11$ & 250 & 300 & $22-24$ \\
\hline HCT 600/ZF100 RBO & 1.2 & $8-10$ & 300 & 350 & $26-30$ \\
\hline HCT 600/ZF100 RBO & 1.8 & $9-11$ & 250 & 350 & $22-24$ \\
\hline DX 52D/ZF140 RBO & 1.5 & $9-12$ & 250 & 300 & 22 \\
\hline DX 53D/AS120 & 0.6 & $8.4-10.4$ & 250 & 250 & 22 \\
\hline DC04/ZE75/75 A & 1.2 & $9.5-12.5$ & 300 & 300 & 22 \\
\hline DC04/ZE75/75 APO & 2.0 & $9.5-12.2$ & 250 & 300 & 22 \\
\hline ZSTE 280BH/ZE75/75 APO & 0.6 & $7.4-10.5$ & 250 & 250 & 22 \\
\hline LAC 320Y400T/ZE/EG + OC2 & 1.5 & $8.8-11.8$ & 250 & 300 & 22 \\
\hline
\end{tabular}




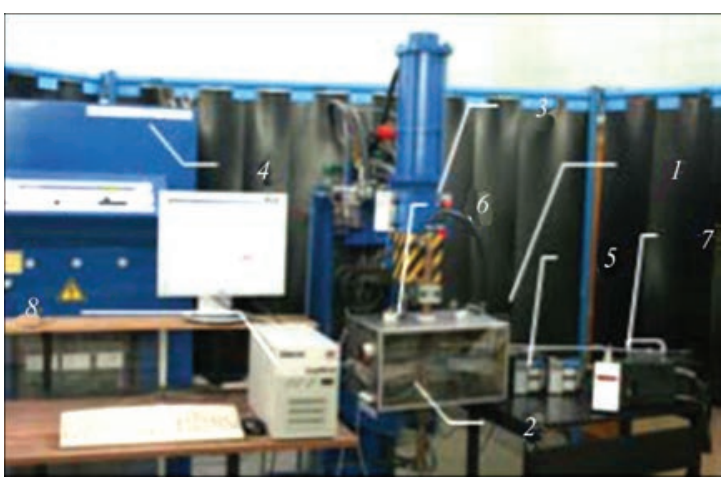

Figure 1. Research station for the examination of fume and gas generation during resistance welding: 1 - fume chamber of $0.03375 \mathrm{~m}^{3}$; 2 - welded workpiece; 3 - machine of ZPa-130i type; 4 - inverter controller HWS 2102IQ; 5 - aspirators; 6 fume filter; 7 - gas analyser Testo-33/Testo-350; 8 - system for measuring and monitoring welding parameters

ments of PN-EN ISO 15011 standard [12-15]. Sampling of fume aimed at the specification of total fume generation is based on the gravimetric method. The principle of the examination is sampling the fume onto the measuring filters during resistance welding with productivity of 20-30 weld $/ \mathrm{min}$, in the hermetic chamber when exhaust system is switched on. It was assumed that the welding process duration in the chamber should be $60 \mathrm{~s}$, since this time makes possible to obtain the increase of fume in the measuring filter enough to determine the mass of collected fume with the accuracy of up to $0.1 \mathrm{mg}$.

The examination of gas generation during resistance welding was conducted using direct method, therefore, analyzers Testo-33 and Testo-350 allowed for direct reading of gas concentration $\left(\mathrm{NO}, \mathrm{NO}_{2}, \mathrm{CO}\right)$ and temperatures. Research methodology, developed initially for the determining inorganic gases generation during resistance welding, suggests the measuring the concentration and emission rate of carbon monoxide and nitrogen oxides. Preliminary research revealed that the nitrogen oxides generation during welding processes is very limited. The conclusion reached during the preliminary research is in the conformity with the assumptions of EN ISO 15011-6:2010 standard [15], which in the case of inorganic gases generation during resistance welding recommends examination of carbon monoxide emission only.

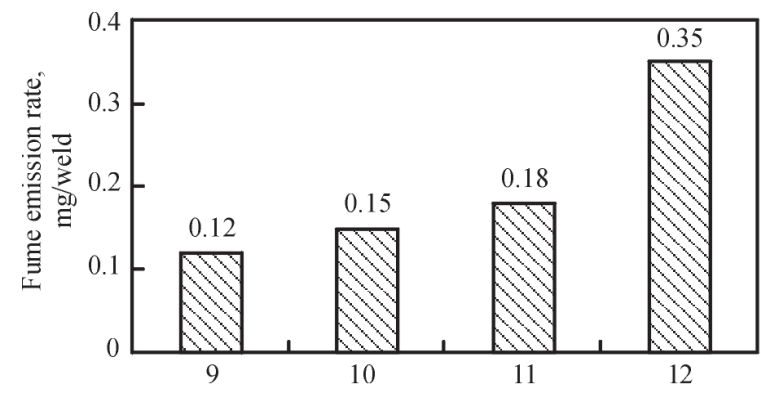

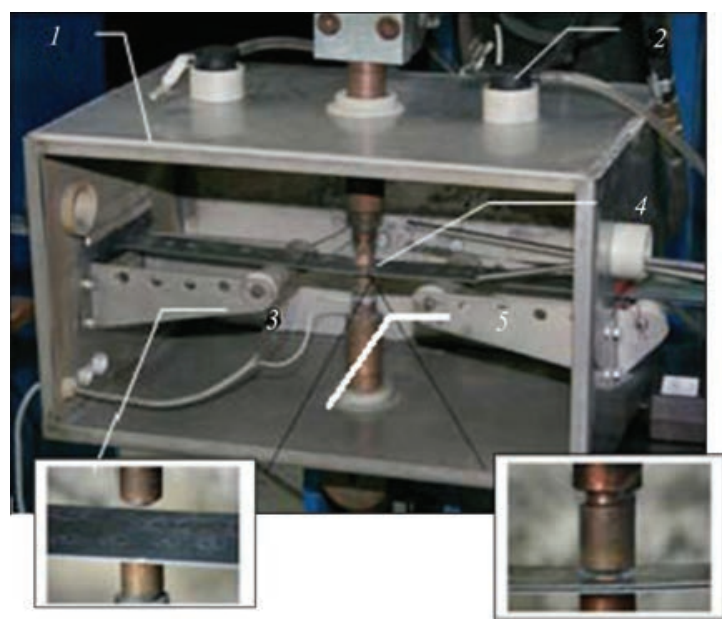

Figure 2. Fume chamber in experimental station for examination of fume and gas emission during spot resistance welding: 1 fume chamber; 2 - fume filter; 3 - welded workpiece; 4 electrodes; 5 - electrode around which welding fume is being formed [11]

Next step of research covered both the determination of chemical composition of fume and the examination of organic substances generation during resistance welding of selected coated plates.

Analysis of research results. The conducted tests of the pollutants generation rates during spot resistance welding of coated plates allowed for the conducting comparative analysis aimed at determination of the effect of welding current and plate thickness on fume and gas generation. The pollutants generation rates in similar welding conditions for different steel grades and various types of the coating were compared as well.

Impact of welding current on fume and gas emission rates. The investigation of fume and carbon monoxide generated during spot resistance welding revealed the impact of welding current on emission rate. Increase in welding current resulted in higher total fume generation and higher generation of carbon monoxide during welding of plates of the same thickness, same welding time and force. The relation between welding current and pollutants emission rate occurred in the case of all coated materials being tested. Taking into consideration welding of DX 53D/

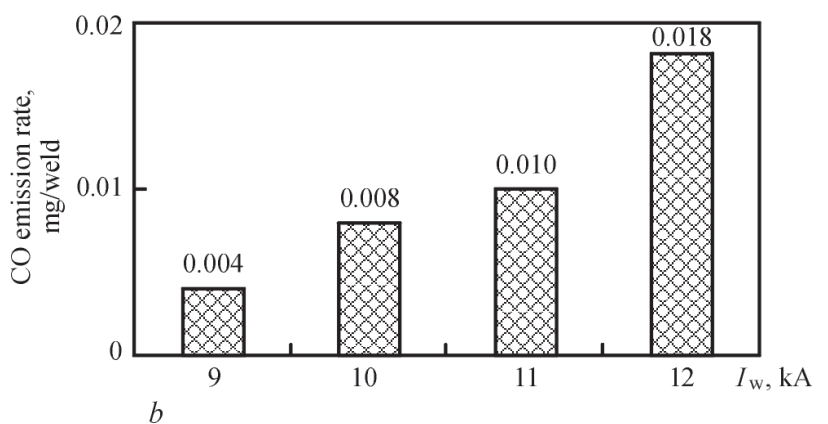

Figure 3. Impact of current on fume $(a)$ and $\mathrm{CO}(b)$ emission rates during spot resistance welding of hot-dip Zn-coated plate DX 53D/ Z140 MBO of $1.5 \mathrm{~mm}$ thickness 

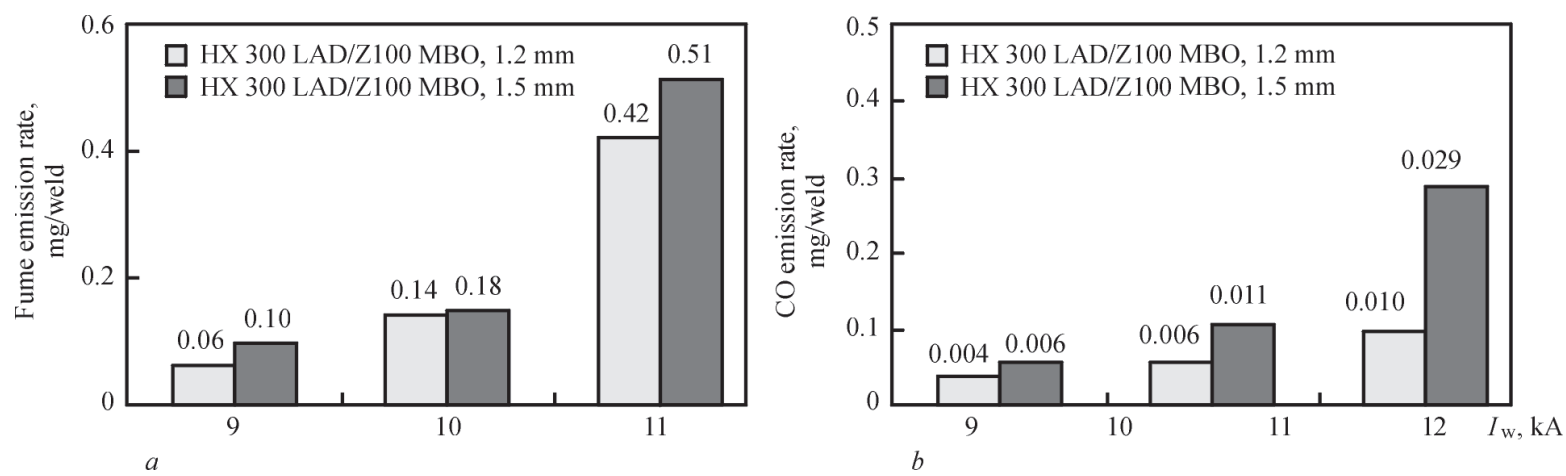

Figure 4. Emission of total fume $(a)$ and $\mathrm{CO}(b)$ during spot resistance welding of HX $300 \mathrm{LAD} / \mathrm{Z} 100 \mathrm{MBO} 1.2$ and $1.5 \mathrm{~mm}$ plates for various welding currents

Z140 MBO material (see Table 2), the increase of welding current from 9 to $12 \mathrm{kA}$ resulted in three-fold fume generation and 4.5 times of $\mathrm{CO}$ emission rate growth (Figure 3).

Impact of thickness of material being welded on pollutants emission rate. The analysis of this issue was conducted for following coated plates: DX 53D/ ZF100 RBO (1.2 and $1.4 \mathrm{~mm}$ thick), HX $300 \mathrm{LAD} /$ Z100 MBO (1.2 and 1.5), HCT 600/ZF100 RBO (1.2 and 1.8$)$ as well as DC04/ZE75/75 A (1.2) and DC04/ ZE75/75 APO (2.0).

During welding HX 300 LAD/Z100 MBO plate, higher fume and $\mathrm{CO}$ emission rates were revealed for the $1.5 \mathrm{~mm}$ thick plate (Figure 4).

In the case of DX 53D/ZF100 RBO material 1.2 and $1.4 \mathrm{~mm}$ thick, for the same welding current, the higher emission of fume occurred for thinner plate. Similar relation took place for HCT 600/ZF100 RBO plates 1.2 and $1.8 \mathrm{~mm}$ thick. For resistance welding of electrolytic zinc-coated plates the comparative analysis was conducted for DC04/ZE75/75, 1.2 and $2.0 \mathrm{~mm}$ thick plates. These plates differed in the additional surface protection: the $1.2 \mathrm{~mm}$ plate did not have any protection while the $2.0 \mathrm{~mm}$ plate was additionally phosphated and oiled (PO type). Higher fume and $\mathrm{CO}$ emission rate for all current values occurred during welding $1.2 \mathrm{~mm}$ thick plate with zinc coating not protected additionally (Figure 5).

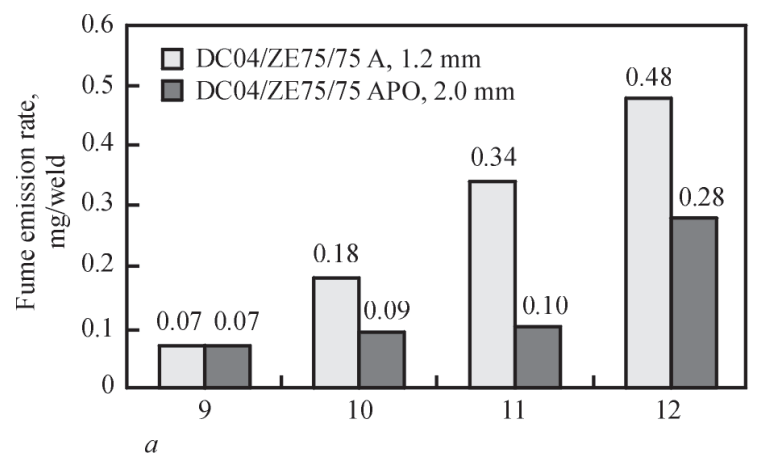

To sum up the research results of the pollutants generation during spot resistance welding, the unequivocal relation between fume and carbon monoxide emission rates and thickness of welded material cannot be established.

Impact of protection coating type on pollutants emission rates. The examination of pollutants emission rate during welding was conducted for five types of coatings differing in the method of applying, chemical composition, thickness and additional protection (Figure 6). The analysis of the research results have revealed that the type of protective coating affects the generation of total fume and carbon monoxide. During resistance welding LAC 320Y400T grade plate with double-layer coating, i.e. electrolytic zinc-coated plate with $5 \mu \mathrm{m}$ thick zinc coating + epoxy protective coating of GardoProtect type, resulted in the highest fume and $\mathrm{CO}$ emission rates in comparison with $\mathrm{Zn}$ and zinc-iron coated plates. Fume generation during zinc- and epoxy-coated plates resistance welding can be even 3-5 times higher than that for hot-dip zinc-coated plates. The analysis of fume and $\mathrm{CO}$ emission rates during welding of hot-dip $\mathrm{Zn}$ - and $\mathrm{Zn}$-Fe-coated plates and electrolytic Zn-coated plates (ZE type coating) revealed that for similar welding conditions, the highest pollutants emission rates occurred for the plates with ZF coating. The plates with $\mathrm{Z}$ and $\mathrm{ZE}$ coating types have similar pollutants emission rates. Research has revealed that fume and

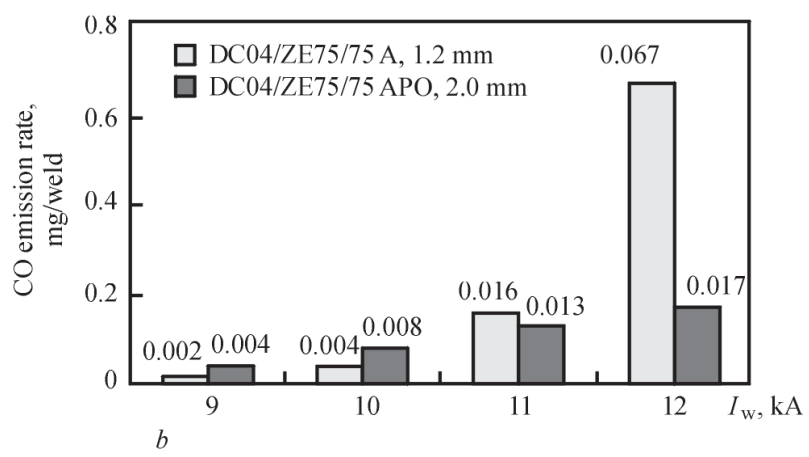

Figure 5. Emission of total fume $(a)$ and $\mathrm{CO}(b)$ during spot resistance welding of $1.2 \mathrm{~mm}$ thick DC04/ZE75/75 A and 2.0 mm thick DC04/ZE75/75 APO plates for various welding currents 


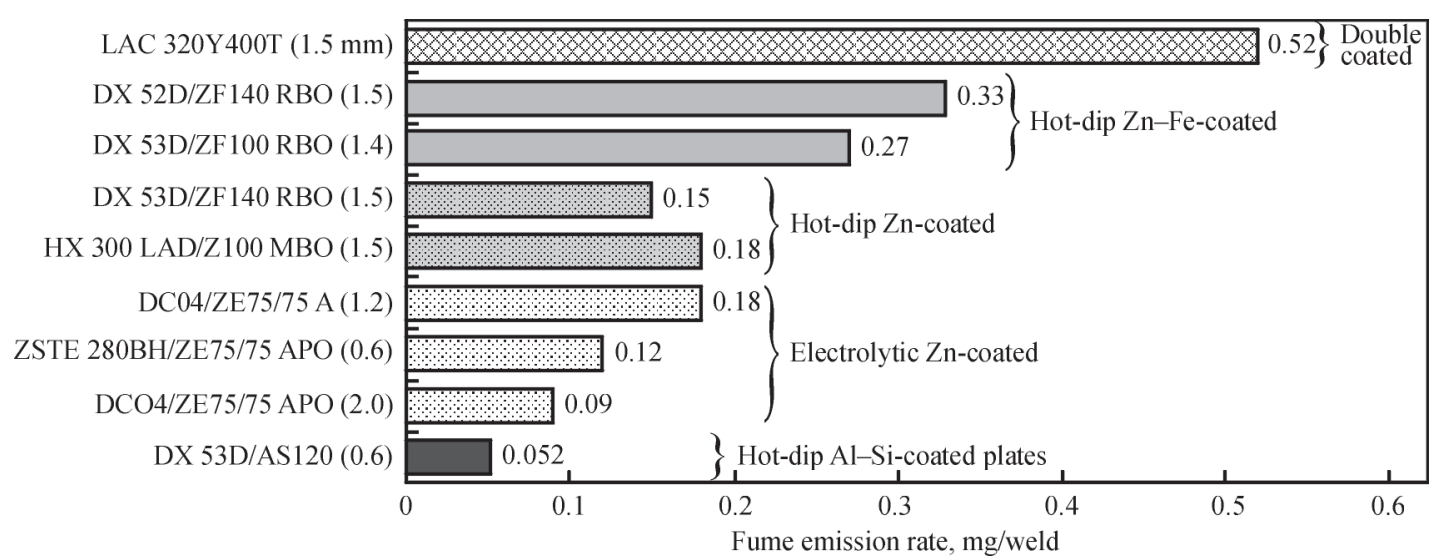

Figure 6. Total fume generation during spot resistance welding plates with various coatings at $I_{\mathrm{w}}=10 \mathrm{kA}$

carbon monoxide emission rates are affected by the type of additional protection of the surface. During resistance welding of electrolytic zinc-coated plates of DC04/ZE75/75 A (no additional protection) and DC04/ZE75/75 APO grade (PO protection), fume generation is $2-3$ times lower for the phosphated and oiled material.

Impact of coating thickness on pollutants emission rates. The analysis of coating thickness influence was carried out for similar material grades and thicknesses. They differed with the coating mass -100 and $140 \mathrm{~g} / \mathrm{m}^{2}-100 \mathrm{~g} / \mathrm{m}^{2}$ referred to coating thickness of $7 \mu \mathrm{m}$, and $140 \mathrm{~g} / \mathrm{m}^{2}$ — to $10 \mu \mathrm{m}$.

In case of hot-dip coated plates with $\mathrm{Z}$ type coating, the research of coating thickness influence was conducted for $\mathrm{HX} 300 \mathrm{LAD} / \mathrm{Z} 100 \mathrm{MBO}$ and HX $420 \mathrm{LAD} / \mathrm{Z} 140 \mathrm{MBO}$ materials $1.2 \mathrm{~mm}$ thick. The test results have shown that fume emission rate was 3-4 times higher for material with thicker coat- ings (Figure 7,a). In case of $\mathrm{CO}$, higher values of emission rate were also connected with Z140 MBO coating type, the difference was even seven-fold for $I_{\mathrm{w}}=10$ and $11 \mathrm{kA}$ (Figure 7,b).

For hot-dip coated plates with ZF type coating the analysis was carried out for two similar material - DX 53D/ZF100 RBO (1.4 mm) and DX 52D/ ZF140 RBO $(1.5 \mathrm{~mm})$. The test results have shown that at $I_{\mathrm{w}}=10$ and $11 \mathrm{kA}$ the fume emission rates were $20 \%$ higher for material with thicker coating (Figure $7, c)$. Also $\mathrm{CO}$ emission rates for the same welding current values were $10 \%$ higher for ZF140 RBO coating type (Figure 7, $d$ ).

To summarize, it is possible to observe directly proportional relation between the coating thickness and the fume and $\mathrm{CO}$ emission rate, namely, the higher the coating thickness, the higher is the pollutant emission rate value.
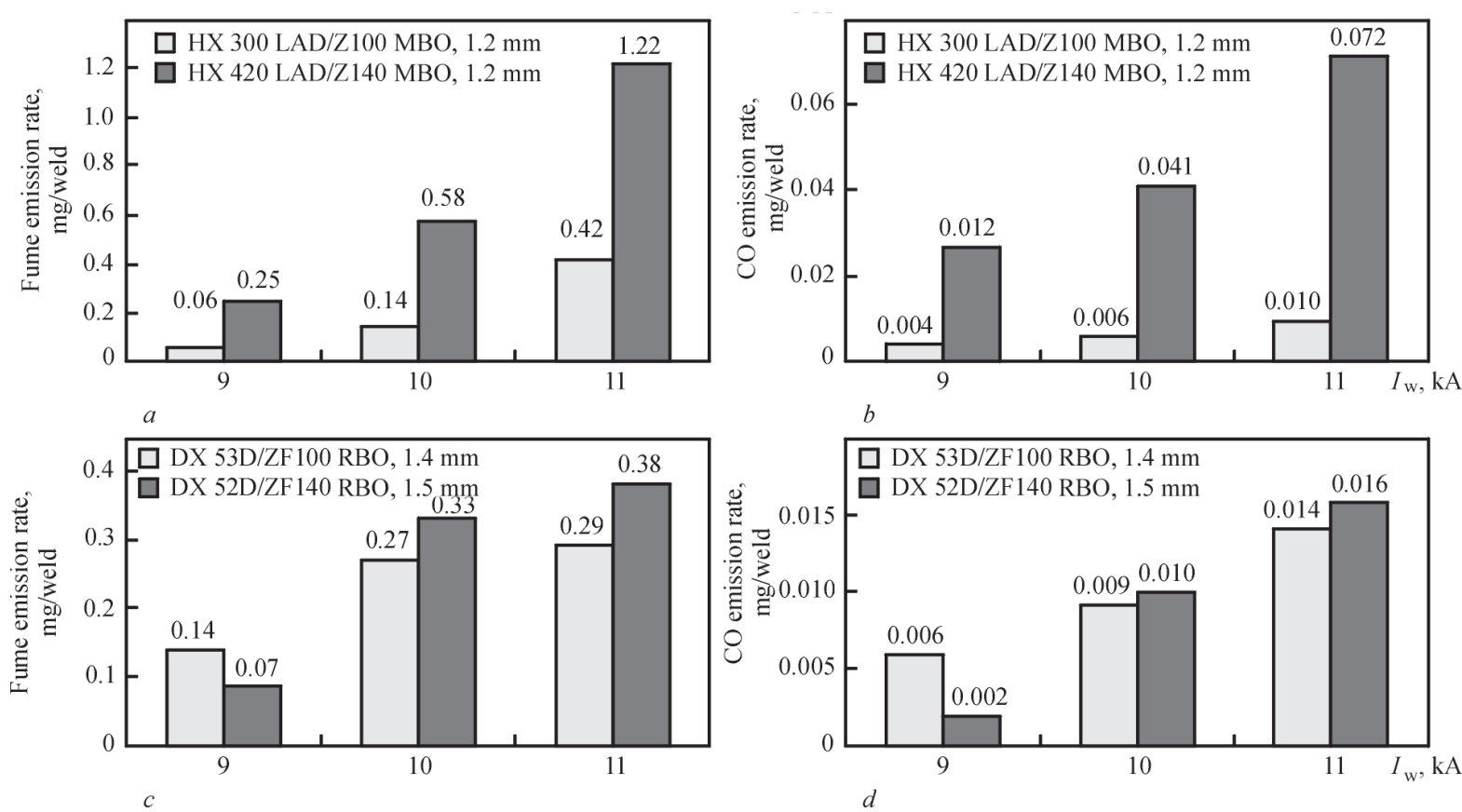

Figure 7. Impact of coating thickness of resistance-welded material on fume and CO emission rates 
Table 3. Chemical composition of fume generated during spot resistance welding of coated plates

\begin{tabular}{|c|c|c|c|c|c|}
\hline \multirow{2}{*}{ Type of coated plates } & \multicolumn{5}{|c|}{ Fume chemical composition, \% } \\
\cline { 2 - 6 } & Fe & Mn & Si & Zn & Al \\
\hline DX 53D/ZF100 RBO & 67.5 & 0.53 & 0.30 & 12.18 & - \\
\hline HCT 600/ZF100 RBO & 69.6 & 1.16 & 0.27 & 8.11 & - \\
\hline HX 300 LAD/Z100 MBO & 64.0 & 0.51 & 0.24 & 18.80 & - \\
\hline HX 260 LAD/Z100 MBO & 62.3 & 0.62 & 0.28 & 16.30 & - \\
\hline DC04/ZE75/75 A & 68.9 & 0.21 & 0.26 & 28.70 & - \\
\hline DC04/ZE75/75 APO & 55.3 & 0.26 & 0.30 & 28.20 & - \\
\hline DX 53D/AS120 & 48.8 & 1.13 & 1.09 & - & 6.21 \\
\hline
\end{tabular}

Chemical composition of fume generated during resistance welding of coated plates. Chemical analysis was conducted for several steel grades with different type of protective coatings. The testing was performed on fume arising for the chosen highest values of welding current (see Table 2). Chemical composition of fume is shown in Table 3.

Zinc content in the fume depended on the type of protective coating. The highest amount occurred during resistance welding of electrolytic zinc-coated plates (ZE75/75 coating thickness of $7.5 \mu \mathrm{m}$ ), the zinc content in fume was $28.2-28.7 \%$. Then during resistance welding of hot-dip zinc-coated plates (Z100 coating thickness of $7 \mu \mathrm{m}$ ) the zinc content in the fume amounted $16.3-18.8 \%$. Meanwhile in the case of plates with $\mathrm{Zn}-\mathrm{Fe}$ alloy coating (ZF100 coating thickness of $7 \mu \mathrm{m}$ ) the zinc content in fume was from 8.11 to $12.18 \%$.

Organic substances emitted during resistance welding of coated plates. The quantitative analysis of organic substances was conducted for selected material grades: HCT 600/ZF100 RBO (1.8), LAC 320Y400T/ZE/EG + OC2 (1.5), DX 53D/ Z140 MBO (1.5) and HX 420 LAD/Z140 MBO (1.2 $\mathrm{mm}$ thick) for $I_{\mathrm{w}}=11 \mathrm{kA}$, and covered three groups of organic compounds:

- for BTEX compounds - benzene, toluene, ethyl benzene and $\mathrm{o}, \mathrm{m}, \mathrm{p}$-xylene;

- for phenol, o-cresol and $\mathrm{m}+\mathrm{p}$ cresol;

- for polycyclic aromatic hydrocarbons - naphthalene, acenaphthylene, fluorene, phenanthrene, ben- zo(a)anthracene, pyrene, chrysene, benzo(a)pyrene, benzo(k)fluoranthene.

The impact of the protection coating type on organic compounds emission rate during spot resistance welding is shown in Figures 8 and 9. Research has revealed that the type of anticorrosive coating and the additional protection technique of the outside layer influence the emission rate and the type of generated organic compounds. The highest generation of benzene - the substance of the proven carcinogenic action - occurred during resistance welding of HCT 600/ZF100 RBO grade plate. This plate was covered with coating of the increased quality from zinc-iron alloy and was additionally protected by oiling (see Figure 8).

The highest generation of three cresol isomers: ortho, meta and para - the substance of the probable carcinogenic action - occurred for plate LAC 320Y400T/ZE/EG + OC2 + GardoProtect 9498 with double-layer coating $1.5 \mathrm{~mm}$ thick at $I_{\mathrm{w}}=11 \mathrm{kA}$.

The analysis of PAHs emission started with benzo(a)pyrene generation, since this hydrocarbon is the most thoroughly examined substance being defined as confirmed carcinogen and benzo(k)fluoranthene the next substance of the high relative carcinogenic coefficient (0.1). Benzo(a)pyrene is the standard compound for the calculation of the carcinogenic action of other PAHs compounds. The highest emission of these substances occurred during welding of oiled zinc-epoxy double-layer coated and chemically passivated plate. In the case of resistance welding of $\mathrm{Zn}$ -

$C, \mu \mathrm{g} / 100$ welds

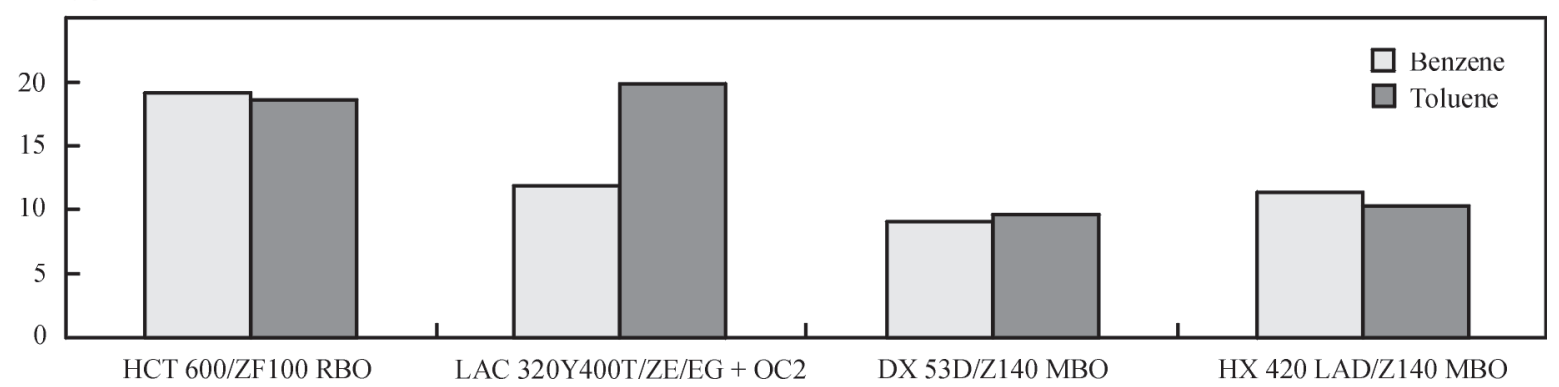

Figure 8. Emission of benzene and toluene during resistance welding of coated plates 


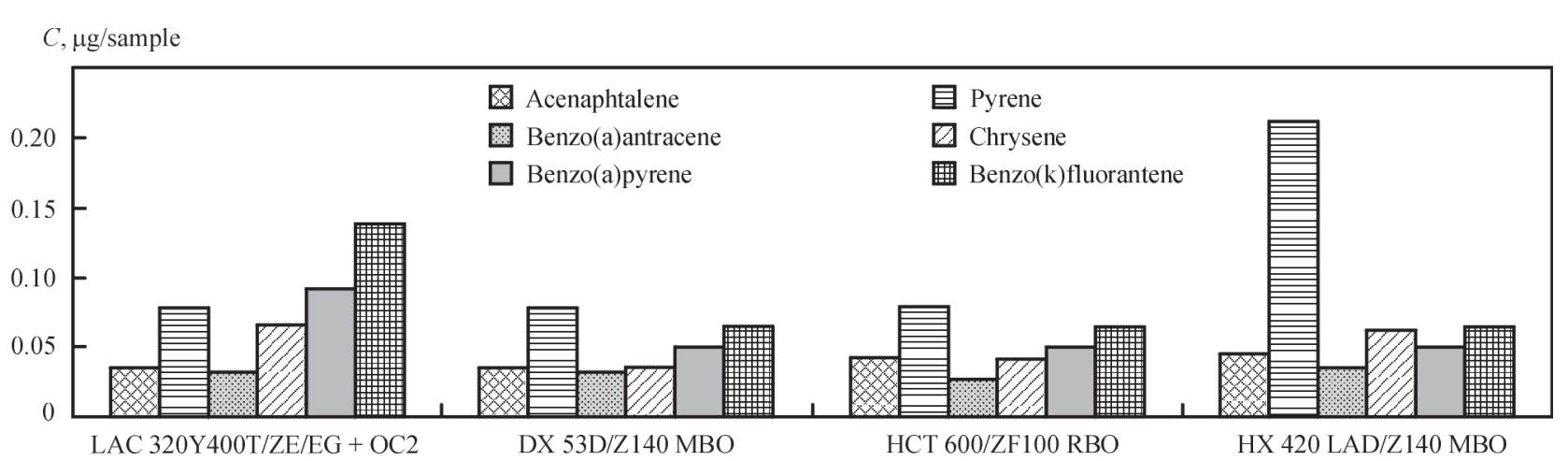

Figure 9. Impact of anticorrosion coating on emission rate of polycyclic aromatic hydrocarbons during resistance welding of plates with various coatings

and $\mathrm{Zn}-\mathrm{Fe}$-coated plates, the emission rates of benzo(a)pyrene and benzo(k)fluoranthene were below their determinability levels.

Also the emission rates of other polycyclic aromatic hydrocarbons identified in welding fumes: pyrene, chrysene and acenaphthalene; these substances are characterised by lower carcinogenic properties (see Figure 9).

All materials with protective coatings being resistance-welded were additionally protected by the oiling and chemical passivation processes. The decomposition of the oil and epoxy resin layers caused emission of organic compounds to the work environment. Especially high emission rate of these substances was associated with resistance welding of double-layer zinc- and epoxy-coated and additionally oiled plates.

\section{Conclusions}

The investigations of pollutants arising during spot resistance welding of plates with various protective coatings conducted at Instytut Spawalnictwa allowed for formulating following conclusions $[8-10,16,17]$.

The fume and gas emission rates in welding depends on current: the increase of current results in higher generation of total fume, carbon monoxide and organic substances in welding of plates of the same thickness and applying the same welding time and welding force. The relation between welding current and pollutants emission rates occurs for all covered materials being tested.

The unequivocal relation between fume and gas emission rates and thickness of the welded material cannot be determined on the basis of the research results of pollutants generation during spot resistance welding of plates with various protective coatings.

The research revealed the impact of the protection coating type on emission rates of the total fume and carbon monoxide, namely, during resistance welding the highest results of fume and $\mathrm{CO}$ were identified for double-coated plates (with zinc-epoxy coating), then for plates with zinc-iron coatings. Plates with zinc and zinc-iron coatings have the similar pollutants emission rates.

The results analysis confirmed the directly proportional relation between the coating thickness and the values of fume and $\mathrm{CO}$ emission rate.

The chemical analysis of fume covered the quantitative determination of $\mathrm{Fe}, \mathrm{Zn}, \mathrm{Si}, \mathrm{Mn}$ and $\mathrm{Al}$ elements. The results of the chemical analysis of the fume being generated during resistance welding of plates with various coatings have revealed that the highest content of zinc in fume occurs in the case of electrolytic zinc-coated plates.

The process of resistance welding steel plates covered with protective coatings is associated with the emission of various organic substances. The compounds of the confirmed carcinogenic character emitted in this process are benzene and benzo(a)pyrene. The substances of suspected carcinogenic action being determined in resistance welding are cresols and polycyclic aromatic hydrocarbons.

This article has been elaborated on the basis of the second stage of long-lasting program «Improvement of occupational safety and work conditions», financed by the Ministry of Science and Higher Education/National Centre for Research and Development in Poland in the range of scientific and development program in 2011-2013. Program coordinator is Central Institute for Labour Protection National Research Institute, Poland.

1. (1999) Austral. Occup. Health and Safety Comm.: Welding fumes and gases.

2. Matczak, W., Gromiec, J.P. (2003) Zasady oceny narażenia zawodowego spawaczy. Łódź: Instytut Med. Pracy.

3. El-Zein, M., Infrnte-Rivard, C. (2005) Is metal fume fever a determinant of welding related respiratory symptoms and /or increased bronchial responsiveness? Occup. Environmental Med., 62, 688-694.

4. Legros, P., Lodi, P. (2008) Spot welding fumes: Characterization of organic coated steels. In: Arcelor Innovation $R \& D$. Belgium.

5. Carter, G., Pengelly, I. (2008) Fume emissions from resistance welding through organic coatings: Establishing a method for generating safety data. In: TWI Report 897/2008. 
6. Legros, P., Winne, V. (2007) Eesistance welding fumes analysis of coated steels. Res. Report. Arcelor Res. Industry, Gent.

7. (2002) Fume emissions from resistance welding: TWI Res. Report.

8. Matusiak, J., Wyciślik, J. et al. (2010) Badania emisji zanieczyszczeń przy zgrzewaniu rezystancyjnym blach z powłokami. In: Res. Report of Institute of Welding, Vol. 105.

9. Matusiak, J., Wyciślik, J. et al. (2011) Analiza wpływu warunków technologicznych innowacyjnych technik spajania różnych materiałów konstrukcyjnych z nowoczesnymi powłokami ochronnymi na stan środowiska pracy. In: Res. Report of Institute of Welding, Ma-34.

10. Matusiak, J., Wyciślik, J. Ocena zagrożeń w środowisku pracy przy zgrzewaniu rezystancyjnym punktowym, zgrzewaniu tarciowym z mieszaniem materiału zgrzeiny oraz zgrzewaniu ultradźwiękowym i wibracyjnym różnych materiałów konstrukcyjnych. Opracowanie zaleceń do profilaktyki zagrożeń z uwzględnieniem modyfikacji warunków technologicznych. In: Zadanie realizowany $w$ 2012. Program wieloletni pn. «Poprawa bezpieczeństwa i warunków pracy» etap II realizowane $w$ latach 2011-2013. Warszawa: Koord. CIOP PIB.

11. PN-EN ISO 5182:2009: Zgrzewanie rezystancyjne — Materiały na elektrody i sprzęt pomocniczy (oryg.).
12. PN-EN ISO 15011-1:2010: Zdrowie i bezpieczeństwo przy spawaniu i procesach pokrewnych - Metoda laboratoryjna pobierania próbek dymu i gazów. Część 1: Określanie wielkości emisji dymu podczas spawania łukowego i pobieranie dymu do analizy.

13. PN-EN ISO 15011-4:2008/A1:2009: Zdrowie i bezpieczeństwo przy spawaniu i procesach pokrewnych — Metoda laboratoryjna pobierania próbek pyłu i gazów. Część 4: Karty charakterystyki pyłu (oryg.)

14. ISO 15011-5:2009: Health and safety in welding and allied processes - Laboratory method for sampling fume and gases. Pt 5: Identification of fume and gases generated during welding and cutting through products composed wholly or partly of organic materials.

15. ISO 15011-6:2010: Health and safety in welding and allied processes - Laboratory method for sampling fume and gases. Pt 6: Procedure for quantitative determination of fume and gases from resistance spot welding.

16. Matusiak, J., Wyciślik, J. (2012) Zgrzewanie rezystancyjne blach stalowych z powłokami a emisja zanieczyszczeń do środowiska pracy. Biul. Instytutu Spawalnictwa, 3, 20-28.

17. Matusiak, J., Wyciślik, J. (2012) Research into fume and gases emission during resistance welding of coated steels plates. Hutnik - Wiadomości hutnicze, 11, 805-816.

Received 22.03.2016 